\title{
М.В. Язвинська
}

канд. геол. наук, старш. наук. співроб.

Науково-організаційного відділу Президії НАН України

e-mail:Yazvynska@nas.gov.ua

https://orcid.org/0000-0002-1074-7525

\section{А.І. Радченко}

канд. геол. наук, заступник директора з питань наукової та видавничої

діяльності Видавничого дому «Академперіодика» НАН України

e-mail: radchenko@nas.gov.ua

https://orcid.org/0000-0002-0276-6398

\section{ПЕРІОДИКА НАН УКРАЇНИ У ДЕЯКИХ НАУКОМЕТРИЧНИХ БАЗАХ ДАНИХ І ПЕРЕЛІКУ НАУКОВИХ ФАХОВИХ ВИДАНЬ УКРАЇНИ}

https://doi.org/10.15407/akademperiodyka.391.046

Проаналізовано входження наукових видань НАН України та ії установ до чотирьох відомих баз даних, серед яких Scopus та Web of Science Core Collection - дві основні для включення видань до категорії А Переліку фахових видань України. Установлено, що кількість академічних видань, відкритих та помітних для світової наукової спільноти, не перевищує $15 \%$. Підкреслено надзвичайно низьку активність академічних видань щодо входження до Переліку наукових фахових видань України, що вже наступного року істотно ускладнить процедури захисту кваліфікаційних робіт та атестування наукових і науково-педагогічних працівників в Україні.

Ключові слова: науковий журнал, наукометрична база, фахове видання, НАН України, Scopus, Web of Science Core Collection, ERICH PLUS, DOAJ, DOI.

Загальнодержавний напрям євроінтеграції, упровадження болонського процесу в освіті, спроби реформування науки й освіти в Україні шляхом ухвалення нових нормативних актів найвищого рівня призвели до підвищення уваги до питання відкритості світові вітчизняних наукових результатів. Для стимулювання наукових установ і закладів вищої освіти до якнайширшого представлення власних здобутків у мережі інтернет останнім часом на різних рівнях державою здійснено низку заходів. Зокрема, іноземний аудит науко-освітньої сфери, започаткування атестації наукових установ, фінансування доступу до наукометричних баз. Однозначно оцінити результати цих заходів поки що складно, але зрозуміло, що вони справили істотний вплив на повсякденне життя наукових установ і закладів вищої освіти, а також на розвиток наукових періодичних видань. 
Найістотнішим для наукової періодики зрушенням стало ухвалення нового Порядку формування Переліку наукових фахових видань України, затвердженого наказом МОН України від 15.01.2018 № 32 (Порядок, Перелік). Ці вимоги базовані на оцінюванні готовності видань до включення їх у світовий науковий інформаційний простір для якнайширшого висвітлення актуальних результатів наукових досліджень в Україні та світі. Зрозуміло, що входження до цього Переліку не може бути критерієм оцінювання наукової значущості видання чи опублікованої у ньому статті, однак безперечно нові вимоги спонукали багато журналів до перегляду власної політики [1-3].

Наявність видання у названому Переліку означає його фаховість за певними напрямами та галузями науки і визнання його придатним для «опублікування основних наукових результатів дисертацій здобувачами наукових ступенів та досліджень претендентів на присвоєння вчених звань; врахування при оцінюванні результатів наукової діяльності закладів вищої освіти і наукових установ; врахування при оцінюванні результатів наукової діяльності та атестації наукових та науково-педагогічних працівників; врахування при оцінюванні проектів науково-дослідних робіт, поданих на конкурси для фінансування за кошти державного чи місцевих бюджетів».

Нині відомо, що до Порядку вже готуються зміни, але навряд чи вони вплинуть на ключові його вимоги. Зокрема, Порядок визначає, що до наукових фахових видань можуть належать лише такі, які мають окремий сайт видання, коди $D O I$ на вміщені у виданні матеріали, наявність видання у наукометричних чи реферативних базах даних (БД). До того ж Порядок передбачає певне ранжування видань: до категорії А можуть належати видання, що входять до наукометричних БД Scopus та Web of Science Core Collection (WoS CC), до категорії Б - видання, що входять до інших різноманітних баз та отримують коди DOI, до категорії В - решта видань, що входили до Переліку до ухвалення нових вимог. Категорія В має фактично припинити існування 13 березня 2020 року, тож до того часу видання, яке хоче продовжити власне існування як фахове, повинно пройти відповідну процедуру перереєстрації у МОН України й отримати категорію Б чи А. Цю процедуру видання фактично могли розпочати з дати набуття чинності названим наказом МОН України, тобто з 13 березня 2018 року.

Загалом установи НАН України видають 341 видання, серед яких 154 збірники та 187 журналів. Традиційно серед них виділяють видання, до складу співзасновників яких НАН України входить як юридична особа. Таких видань на сьогодні 125 (36,7 \% від загальної кількості), у тому числі 89 журналів та 36 збірників. Представлені нижче розрахунки виконано з урахуванням усієї сукупності видань НАН України та ії установ. Варто пам'ятати, що видання НАН України становлять близько 14 \% від загальної кількості наукових періодичних видань, що входять до попередньої версії Переліку наукових фахових видань України й вважатимуться фаховими до 13 березня 2020 року.

Станом на 11.07.2019 до категорій А та Б нового Переліку наукових фахових видань України з майже 2,5 тисяч вітчизняних видань увійшло 189 
[4]. Тобто близько 7 \%. Серед них 44 видання, до складу засновників яких входять НАН України як юридична особа та / або приналежні до неї установи. До категорії А увійшло 34 видання, до категорії Б - 10 (табл. 1). Це становить лише 13,6 \% від усіх видань НАН України та ії установ. При цьому Секцію фізико-технічних і математичних наук НАН України представляють 28 видань, Секцію хімічних і біологічних наук - 14, Секцію суспільних і гуманітарних наук - 2 .

Таблиия 1. Входження наукових періодичних видань НАН України до Переліку наукових фахових видань України (категорії А та Б)

\begin{tabular}{|c|c|c|c|}
\hline \multirow{2}{*}{$\begin{array}{l}\text { Номер } \\
\text { з/п }\end{array}$} & \multirow{2}{*}{ Назва видання } & \multicolumn{2}{|c|}{ Категорія } \\
\hline & & A & Б \\
\hline 1 & Альгологія / International Journal on Algae & + & - \\
\hline 2 & Біотехнологія / Biotechnologia Acta & - & + \\
\hline 3 & Вісник зоології / Vestnik Zoologii & + & - \\
\hline 4 & Гідробіологічний журнал / Hydrobiological journal & + & - \\
\hline 5 & Економіка. Екологія. Соціум / Economics. Ecology. Socium & - & + \\
\hline 6 & Економіка харчової промисловості / Food Industry Economics & - & + \\
\hline 7 & Електронне моделювання / Electronic modeling & - & + \\
\hline 8 & $\begin{array}{l}\text { Електротехніка і електромеханіка / Electrical Engineering \& } \\
\text { Electromechanics }\end{array}$ & + & - \\
\hline 9 & $\begin{array}{l}\text { Здобутки астрономії та фізики космосу / Advances in Astronomy and } \\
\text { Space Physics }\end{array}$ & + & - \\
\hline 10 & $\begin{array}{l}\text { Журнал математичної фізики, аналізу, геометрії / Journal of } \\
\text { Mathematical Physics Analysis Geometry }\end{array}$ & + & - \\
\hline 11 & Кібернетика і системний аналіз / Cybernetics and Systems Analysis & + & - \\
\hline 12 & $\begin{array}{l}\text { Кінематика і фізика небесних тіл / Kinematics and physics of celestial } \\
\text { bodies }\end{array}$ & + & - \\
\hline 13 & $\begin{array}{l}\text { Математичні методи та фізико-механічні поля / Journal of } \\
\text { Mathematical Sciences }\end{array}$ & + & - \\
\hline 14 & Мікробіологічний журнал / Mikrobiolohichnyi Zhurnal & - & + \\
\hline 15 & Надтверді матеріали / Journal of Superhard Materials & + & - \\
\hline 16 & Наука та інновації / Science and Innovation & + & - \\
\hline 17 & Нейрофізіологія / Neurophysiology & + & - \\
\hline 18 & Нелінійні коливання / Journal of Mathematical Sciences & + & - \\
\hline 19 & Порошкова металургія / Powder Metallurgy and Metal Ceramics & + & - \\
\hline 20 & $\begin{array}{l}\text { Праці Інституту електродинаміки НАН України / Works of the } \\
\text { Institute of Electrodynamics of the NAS of Ukraine }\end{array}$ & - & + \\
\hline 21 & Прикладна механіка / International Applied Mechanics & + & - \\
\hline 22 & $\begin{array}{l}\text { Проблеми керування та інформатики / Journal of Automation and } \\
\text { Information Sciences }\end{array}$ & + & - \\
\hline 23 & $\begin{array}{l}\text { Проблеми кріобіології і кріомедицини / Problems of Cryobiology and } \\
\text { Cryomedicine }\end{array}$ & + & - \\
\hline
\end{tabular}


Закінчення табл. 1

\begin{tabular}{|c|c|c|c|}
\hline \multirow{2}{*}{$\begin{array}{l}\text { Номер } \\
3 / \Pi\end{array}$} & \multirow{2}{*}{ Назва видання } & \multicolumn{2}{|c|}{ Категорія } \\
\hline & & A & Б \\
\hline 24 & Проблеми міцності / Strength of Materials & + & - \\
\hline 25 & $\begin{array}{l}\text { Теоретична і експериментальна хімія / Theoretical and Experimental } \\
\text { Chemistry }\end{array}$ & + & - \\
\hline 26 & Технічна електродинаміка / Technical Electrodynamics & + & - \\
\hline 27 & $\begin{array}{l}\text { Український біохімічний журнал / The Ukrainian Biochemical } \\
\text { Journal }\end{array}$ & + & - \\
\hline 28 & $\begin{array}{l}\text { Український ентомологічний журнал / Ukrainian Entomological } \\
\text { Journal }\end{array}$ & - & + \\
\hline 29 & Український математичний вісник / Ukrainian Mathematical Bulletin & + & - \\
\hline 30 & Український математичний журнал / Ukrainian Mathematical Journal & + & - \\
\hline 31 & Український фізичний журнал / Ukrainian Journal of Physics & + & - \\
\hline 32 & Успіхи фізики металів / Progress in Physics of Metals & + & - \\
\hline 33 & Фізика конденсованих систем / Condensed Matter Physics & + & - \\
\hline 34 & Фізика низьких температур / Low Temperature Physics & + & - \\
\hline 35 & Фізико-хімічна механіка матеріалів / Materials Science & + & - \\
\hline 36 & Фізіологічний журнал / Fiziolohichnyi Zhurnal & - & + \\
\hline 37 & Фізіологія рослин і генетика / Plant Physiology and Genetics & - & + \\
\hline 38 & $\begin{array}{l}\text { Хімія, фізика та технологія поверхні / Chemistry, Physics and } \\
\text { Technology of Surface }\end{array}$ & - & + \\
\hline 39 & Цитологія і генетика / Cytology and Genetics & + & - \\
\hline 40 & Ядерна фізика та енергетика / Nuclear Physics And Atomic Energy & + & - \\
\hline 41 & Functional Materials & + & - \\
\hline 42 & Methods of Functional Analysis and Topology & + & - \\
\hline 43 & Semiconductor Physics Quantum Electronics \& Optoelectronics & + & - \\
\hline 44 & Theory of Stochastic Processes & + & - \\
\hline Загало & м назв видань & 34 & 10 \\
\hline
\end{tabular}

Примітка. Назви видань у табл. 1-3 наведено спочатку основною мовою видання (українською чи англійською), паралельно також англійською або у транслітерованому латиницею вигляді так, як вони фігурують у БД.

Одною з необхідних умов для входження до категорії Б та до світових наукометричних баз даних $є$ отримання виданням цифрових ідентифікаторів об'єктів DOI для наукових статей. Ці коди є стійкими унікальними гіперпосиланнями на домашні сторінки статей у наукових періодичних виданнях, монографії та розділи у них, інші елементи видання (таблиці, рисунки). Ці вбудовані посилання забезпечують прямий зв'язок з опублікованим елементом та $€$ незмінними навіть у разі зміни видавця, хостінгу чи назви видання: користуючись DOI, пошукач має за один крок дійти до потрібної публікації $[5,6]$. Сенс використання цифрових ідентифікаторів полягає у тому, що незалежно від мови основного тексту матеріалу його метадані розміщуються 
у мережі англійською мовою за уніфікованою формою, а весь масив інформації є зв'язаним перехресними посиланнями. Тобто механізм крос-лінкінгу працює у повному обсязі, забезпечуючи зростання кількості цитувань як усього масиву даних, так і кожної публікації зокрема [5].

У різних країнах наукові видання отримують ці коди від резидентів CrossRef. Саме CrossRef здійснює управління та веде регулярно оновлювану інформаційну базу даних, що складається з оригінальних опублікованих праць, їхніх метаданих і цифрових ідентифікаторів DOI, які є певним сталим шляхом до кожної публікації, забезпечує наявність у електронному просторі метаданих щодо кожного з об’єктів, що одержав цифровий ідентифікатор DOI. В Україні є декілька резидентів CrossRef, переважна більшість журналів НАН України та ії установ отримують коди у Передплатному агентстві «Укрінформнаука», це 66 видань (близько 20 \% академічної періодики) [6].

Наявність DOI нині є необхідною умовою й для включення видання у міжнародні наукометричні БД, серед яких і Директорія журналів відкритого доступу (Directory Open Access Journals, DOAJ), рекомендована як провідна відкрита платформа для реалізації ініціатив, відомих як План $S$ в Європейському Союзі [7].

Нижче наведено результати аналізування наявності у базах даних Scopus, Web of Science Core Collection, ERICH PLUS, DOAJ видань НАН України та іï установ [8-11]. Результати наведено станом на 10.08.2019 (табл. 2, 3). Ключовий параметр пошуку - країна походження видання (Ukraine).

Таблиия 2. Входження наукових періодичних видань НАН України до БД Scopus та Web of Science Core Collection

\begin{tabular}{|c|c|c|c|}
\hline $\begin{array}{c}\text { Номер } \\
3 / \Pi\end{array}$ & Назва видання & Scopus & $\begin{array}{c}\text { Web of } \\
\text { Science } \\
\text { CC }\end{array}$ \\
\hline 1 & Альгологія / International Journal on Algae & + & + \\
\hline 2 & Вісник зоологіï / Vestnik Zoologii & + & + \\
\hline 3 & Геодинаміка / Geodynamics & - & + \\
\hline 4 & Геофізичний журнал / Geofizicheskiy Zhurnal & - & + \\
\hline 5 & Гідробіологічний журнал / Hydrobiological journal & + & + \\
\hline 6 & $\begin{array}{l}\text { Доповіді Національної академії наук України / Reports of the } \\
\text { National Academy of Science of Ukraine }\end{array}$ & - & + \\
\hline 7 & Економічний часопис - XXI / Economic Annals - XXI & + & + \\
\hline 8 & $\begin{array}{l}\text { Електротехніка і електромеханіка / Electrical Engineering \& } \\
\text { Electromechanics }\end{array}$ & - & + \\
\hline 9 & $\begin{array}{l}\text { Журнал математичної фізики, аналізу, геометрії / Journal of } \\
\text { Mathematical Physics Analysis Geometry }\end{array}$ & + & + \\
\hline 10 & Кібернетика і системний аналіз / Cybernetics and Systems Analysis & + & + \\
\hline 11 & $\begin{array}{l}\text { Кінематика і фізика небесних тіл / Kinematics and physics of } \\
\text { celestial bodies }\end{array}$ & + & + \\
\hline
\end{tabular}


Продовження табл. 2

\begin{tabular}{|c|c|c|c|}
\hline $\begin{array}{c}\text { Номер } \\
\text { з/п }\end{array}$ & Назва видання & Scopus & $\begin{array}{c}\text { Web of } \\
\text { Science } \\
\text { CC }\end{array}$ \\
\hline 12 & $\begin{array}{l}\text { Космічна наука і технологія / Space Science and Technology / } \\
\text { Kosmicna Nauka i Tehnologia }\end{array}$ & - & + \\
\hline 13 & $\begin{array}{l}\text { Математичні методи та фізико-механічні поля / Journal of } \\
\text { Mathematical Sciences }\end{array}$ & + & - \\
\hline 14 & $\begin{array}{l}\text { Металофізика та новітні технологіï / Metallophysics and } \\
\text { Advanced Technologies }\end{array}$ & + & - \\
\hline 15 & Мікробіологічний журнал / Mikrobiolohichnyi Zhurnal & $t^{*}$ & - \\
\hline 16 & Надтверді матеріали / Journal of Superhard Materials & + & + \\
\hline 17 & $\begin{array}{l}\text { Наносистеми, наноматеріали, нанотехнологіï / Nanosistemi, } \\
\text { Nanomateriali, Nanotehnologii }\end{array}$ & + & - \\
\hline 18 & Наука та інновації / Science and Innovation & - & + \\
\hline 19 & Нейрофізіологія / Neurophysiology & + & + \\
\hline 20 & Нелінійні коливання / Journal of Mathematical Sciences & + & - \\
\hline 21 & $\begin{array}{l}\text { Питання атомної науки і техніки / Problems of Atomic Science } \\
\text { and Technology, Series Thermonuclear Fusion }\end{array}$ & + & + \\
\hline 22 & Порошкова металургія / Powder Metallurgy and Metal Ceramics & + & + \\
\hline 23 & Прикладна механіка / International Applied Mechanics & + & + \\
\hline 24 & $\begin{array}{l}\text { Проблеми керування та інформатики / Journal of Automation } \\
\text { and Information Sciences }\end{array}$ & + & - \\
\hline 25 & $\begin{array}{l}\text { Проблеми кріобіології і кріомедицини / Problems of Cryobiology } \\
\text { and Cryomedicine }\end{array}$ & + & - \\
\hline 26 & Проблеми міцності / Strength of Materials & + & + \\
\hline 27 & $\begin{array}{l}\text { Радіофізика та електроніка / Telecommunications and Radio } \\
\text { Engineering }\end{array}$ & + & - \\
\hline 28 & $\begin{array}{l}\text { Теоретична і експериментальна хімія /Theoretical and } \\
\text { Experimental Chemistry }\end{array}$ & + & + \\
\hline 29 & Термоелектрика / Journal of Thermoelectricity & $+^{*}$ & - \\
\hline 30 & Технічна електродинаміка / Technical Electrodynamics & + & - \\
\hline 31 & $\begin{array}{l}\text { Український біохімічний журнал / The Ukrainian Biochemical } \\
\text { Journal }\end{array}$ & + & + \\
\hline 32 & Український ботанічний журнал / Ukrainian Botanical Journal & - & + \\
\hline 33 & $\begin{array}{l}\text { Український географічний журнал / Ukrainian Geographical } \\
\text { Journal }\end{array}$ & + & - \\
\hline 34 & Український історичний журнал / Ukrainskyi Istorychnyi Zhurnal & - & + \\
\hline 35 & $\begin{array}{l}\text { Український математичний вісник / Ukrainian Mathematical } \\
\text { Bulletin }\end{array}$ & + & - \\
\hline 36 & $\begin{array}{l}\text { Український математичний журнал / Ukrainian Mathematical } \\
\text { Journal }\end{array}$ & + & + \\
\hline 37 & Український фізичний журнал / Ukrainian Journal of Physics & + & + \\
\hline 38 & Успіхи фізики металів / Progress in Physics of Metals & + & + \\
\hline 39 & Фізика конденсованих систем / Condensed Matter Physics & + & + \\
\hline
\end{tabular}


Закінчення табл. 2

\begin{tabular}{|c|c|c|c|}
\hline $\begin{array}{l}\text { Номер } \\
3 / \Pi\end{array}$ & Назва видання & Scopus & $\begin{array}{c}\text { Web of } \\
\text { Science } \\
\text { CC }\end{array}$ \\
\hline 40 & Фізика низьких температур / Low Temperature Physics & + & + \\
\hline 41 & Фізико-хімічна механіка матеріалів / Materials Science & + & + \\
\hline 42 & Фізіологічний журнал / Fiziolohichnyi Zhurnal & + & - \\
\hline 43 & Хімія і технологія води / Journal of Water Chemistry and Technology & $+^{*}$ & + \\
\hline 44 & Цитологія і генетика / Cytology and Genetics & + & + \\
\hline 45 & Ядерна фізика та енергетика / Nuclear Physics And Atomic Energy & + & + \\
\hline 46 & Advances in Astronomy and Space Physics & - & + \\
\hline 47 & Algebra and Discrete Mathematics & + & + \\
\hline 48 & Avtomaticheskaya svarka & $t^{*}$ & - \\
\hline 49 & Biopolymers and Cell & + & + \\
\hline 50 & Experimental Oncology & + & + \\
\hline 51 & Functional Materials & + & + \\
\hline 52 & Methods of Functional Analysis and Topology & + & + \\
\hline 53 & Modern Phytomorphology & - & + \\
\hline 54 & Semiconductor Physics Quantum Electronics \& Optoelectronics & - & + \\
\hline 55 & Sententiae & + & - \\
\hline 56 & $\begin{array}{l}\text { Symmetry, Integrability and Geometry: Methods and Applications / } \\
\text { SIGMA }\end{array}$ & + & + \\
\hline 57 & Tekhnicheskaya diagnostika i nerazrushayushchiy control & $+^{*}$ & - \\
\hline 58 & Theory of Stochastic Processes & + & - \\
\hline 59 & Ukrainskij Khimicheskij Zhurnal & $+^{*}$ & - \\
\hline \multicolumn{2}{|c|}{ Загалом назв видань } & 48 & 41 \\
\hline
\end{tabular}

Примітка. Астериском відмічені видання, наявні у відповідній БД, індексування яких нині припинено.

Таблиия 3. Входження наукових періодичних видань НАН України до БД ERICH PLUS та DOAJ

\begin{tabular}{|c|l|c|c|}
\hline $\begin{array}{c}\text { Номер } \\
\text { з/п }\end{array}$ & \multicolumn{1}{|c|}{ Назва видання } & $\begin{array}{c}\text { ERICH } \\
\text { PLUS }\end{array}$ & DOAJ \\
\hline 1 & Демографія та соціальна економіка / Demography and social & & \\
2 & есопоту & + & - \\
3 & Доповіді Національної академії наук Україи & - & + \\
4 & Економіка. Екологія. Соціум / Есопотісs. Ecology. Socium & - & + \\
5 & Економіка промисловості / Есопоту of Industry & + & - \\
6 & Економіка та право / Есопотісs and Law & + & + \\
7 & Економічний часопис - ХХІ / Economic Annals - XXI & + & - \\
& Електротехніка і електромеханіка / Electrical Engineering \& & & + \\
\hline
\end{tabular}


Закінчення табл. 3

\begin{tabular}{|c|c|c|c|}
\hline $\begin{array}{l}\text { Номер } \\
\text { з/п }\end{array}$ & Назва видання & $\begin{array}{c}\text { ERICH } \\
\text { PLUS }\end{array}$ & $D O A J$ \\
\hline 8 & EMIHAK & + & - \\
\hline 9 & Інтродукція рослин / Plant Introduction & - & + \\
\hline 10 & $\begin{array}{l}\text { Кібернетика та обчислювальна техніка / Cybernetics and } \\
\text { Computer Engineering }\end{array}$ & - & + \\
\hline 11 & Наука та інновації / Science and Innovation & - & + \\
\hline 12 & $\begin{array}{l}\text { Наукові праці Національної бібліотеки України імені B.I. } \\
\text { Вернадського / Academic Papers of Vernadsky National Library of } \\
\text { Ukraine }\end{array}$ & - & + \\
\hline 13 & Праці теріологічної школи / Theriologia Ukrainica & - & + \\
\hline 14 & $\begin{array}{l}\text { Рукописна та книжкова спадщина України. Археографічні } \\
\text { дослідження унікальних архівних та бібліотечних фондів / } \\
\text { Rukopisna ta knižkova spadŝina Ukraïni }\end{array}$ & - & + \\
\hline 15 & Світогляд Філософія Релігія / Worldview Philosophy Religion & + & - \\
\hline 16 & $\begin{array}{l}\text { Системні дослідження та інформаційні технології / System } \\
\text { research and information technologies }\end{array}$ & - & + \\
\hline 17 & Схід / SKHID & + & + \\
\hline 18 & Українська біографістика / Biographistica ukrainica & + & + \\
\hline 19 & Український соціум (Ukrainian society) & + & - \\
\hline 20 & $\begin{array}{l}\text { Український біохімічний журнал / The Ukrainian Biochemical } \\
\text { Journal }\end{array}$ & - & + \\
\hline 21 & Фізика конденсованих систем / Condensed Matter Physics & - & + \\
\hline 22 & Biopolymers and Cell & - & + \\
\hline 23 & Biotechnologia Acta & - & + \\
\hline 24 & Methods of Functional Analysis and Topology & - & + \\
\hline 25 & Modern Phytomorphology & - & + \\
\hline 26 & Semiconductor Physics Quantum Electronics \& Optoelectronics & - & + \\
\hline 27 & $\begin{array}{l}\text { Symmetry, Integrability and Geometry: Methods and Applications / } \\
\text { SIGMA) }\end{array}$ & - & + \\
\hline \multicolumn{2}{|c|}{ Загалом назв видань } & 9 & 21 \\
\hline
\end{tabular}

Проте не усі наші видання можна віднайти за цим критерієм унаслідок некоректно поданих або несвоєчасно оновлених даних, тому було здійснено перевірку інформації щодо входження видань НАН України до цих баз додатково за їхніми паперовими версіями, власними електронними ресурсами, інформацією Національної бібліотеки України імені В.I. Вернадського, а також шляхом пошуку у базах за кодом ISSN. Найчастіше не афілійовані з Україною та не можуть бути виявлені за відповідним пошуковим запитом ті періодичні наукові видання, випуск яких англійською мовою здійснюють закордонні видавці, які і представляють їх у різноманітних БД [12]. Саме через ці ускладнення представлена нами інформація може бути неповною. Од- 
нак дана ситуація у черговий раз акцентує увагу на важливості коректного зазначення країни походження видання, його афіліації, афіліації головного редактора, членів редакційної колегії й авторів.

У наукометричній БД Scopus за країною походження видання (Ukraine) можна віднайти 54 назви вітчизняних видань, половина з яких - 27 видань - афілійовані з НАН України та їі установами [9]. Окрім цих 27 видань БД Scopus індексує чи індексувала раніше 18 видань, поданих закордонними видавцями. Так відбувається у випадках, коли наукове видання, яке виходить в Україні державною мовою, за кордоном перевидають англійською мовою інші видавці на підставі відповідних угод. Таким чином, загальна кількість видань НАН України, наявних та проіндексованих у БД Scopus, складає 48 (табл. 2), тобто приблизно 14 \% від загальної кількості академічних видань.

У БД $W o S$ CC за пошуковим критерієм країни видання з віднайдених 77 вітчизняних видань 29 видань приналежні до НАН України та ії установ [10]. За вказаними вище додатковими пошуковими критеріями встановлено загальну кількість видань НАН України та їі установ, що присутні в базі WoS $C C,-41$, що складає майже 12 \% від загальної кількості академічних видань (див. табл. 2). 3 них 15 видань представлені закордонними видавництвами.

Поступово до різноманітних БД входять і видання гуманітарного профілю, однак дуже повільно. Наприклад, гуманітарним виданням НАН України варто звернути увагу на БД ERICH PLUS. Ця база розроблена та упроваджена європейськими дослідниками за координації Постійного комітету 3 гуманітарних наук (SCH) Європейського наукового фонду $(E S F)$ для гуманітарних та соціологічних наук і нині є одним із найпрестижніших індексів у Європейському Союзі у галузі гуманітарних та суспільних наук. Зокрема, у Польщі входження до ERICH PLUS є основним критерієм для віднесення періодичних видань соціогуманітарного спрямування до однієї з категорій національного переліку наукових фахових видань [13].

3-понад ста вітчизняних видань, присутніх у БД ERICH PLUS [11], знаходимо дев'ять журналів НАН України (табл. 3), тобто 2,6 \% від загальної кількості академічних видань або 5,3 \% від кількості видань Секції суспільних і гуманітарних наук.

Важливим критерієм визнання журналу як фахового нині $є$ входження до міжнародного мультидисциплінарного каталогу журналів відкритого доступу DOAJ. Саме цю БД, як зазначено вище, визнано пріоритетною для досягнення мети Плану $S$ як намагання зробити науку відкритою, а результати наукових досліджень - безкоштовно доступними будь-якому користувачеві [7]. У ній за пошуковим критерієм Ukraine віднаходимо 245 вітчизняних видань, серед яких 21 академічне (див. табл. 3), що складає близько 6 \% від усіх наукових періодичних видань НАН України.

Висновки. Підсумовуючи викладене, варто ще раз звернути увагу на дуже повільне входження видань НАН України до світових баз даних. На заваді цьому рухові найчастіше стають формальні ознаки, адже рівень видань, представницьке коло авторів і членів редакційних колегій, рівень рецензу- 
вання та наукова значущість результатів у академічних журналах забезпечені здебільшого на високому рівні.

Прикро, що саме формальні ознаки можуть також не дати можливості журналам із тривалою історією та гарними науковими традиціями, що представляють напрацювання певних наукових шкіл Академії, увійти до переліку наукових фахових видань України. Адже часу на перереєстрацію залишилось обмаль. А це істотно скоротить кількість видань високого рівня, де можна буде публікувати результати наукових досліджень для захисту дисертацій та атестації наукових працівників.

\section{СПИСОК ВИКОРИСТАНИХ ДЖЕРЕЛ}

1. Котляревський Я.В., Радченко А.І., Мельников О.В., Семенюк Е.П. Про стратегічні пріоритети вимірювання публікаційної та видавничої активності в науковій діяльності. Наука та інноваціi. 2018. 14 (5). С. 5-18. https://doi.org/10.15407/scin14.05.005

2. Вакаренко О.Г. Наукометричні бази даних: від системи отримання інформації до інструменту оцінювання наукових досліджень. Наука України у світовому інформаційному просторі. Вип. 15. 2018. С. 9-15. https://doi.org/10.15407/akademperiodyka.372.009

3. Тихонкова I.О. Стратегія розвитку наукового видання. Наука України у світовому інформаційному просторі. Вип. 15. 2018. С. 16-27. https://doi.org/10.15407/ akademperiodyka.372.016

4. Перелік наукових фахових видань України, в яких можуть публікуватися результати дисертаційних робіт на здобуття наукових ступенів доктора і кандидата наук (станом на 11 липня 2019 року). URL: https://mon.gov.ua/ua/nauka/nauka/atestaciya-kadrivvishoyi-kvalifikaciyi/naukovi-fahovi-vidannya (дата звернення: 11.08.2019).

5. Методичні рекомендації щодо впровадження цифрових ідентифікаторів у видавничий процес для періодичних видань Національної академії наук України / А.Д. Данілова, А.І. Радченко, Т.М. Яцків; ВД «Академперіодика» НАН України; ПА «Укрінформнаука». 3-є вид., переробл. і доповн. Київ: Академперіодика, 2019. 60 с.

6. Яцків T.M., Данілова А.Д. Надання цифрових ідентифікаторів DOI як один із заходів покращення видимостінаукового журналу. Наука України усвітовомуінформаційному nросторі. Вип. 15. 2018. С. 55-65. https://doi.org/10.15407/akademperiodyka.372.055

7. Making full and immediate Open Access a reality. URL: https://www.coalition-s.org/ (дата звернення: 10.08.2019).

8. Directory of Open Access Journals. URL: https://doaj.org/ (дата звернення: 11.08.2019).

9. Scopus, Scimago Journal \& Country Rank. URL: https://www.scimagojr.com/ (дата звернення: 10.08.2019).

10. Web of Science Core Collection, Master Journal List. URL: http://mjl.clarivate.com/ (дата звернення: 10.08.2019).

11. ERIH PLUS. URL: https://dbh.nsd.uib.no/publiseringskanaler/erihplus/periodical/ info?id=485395 (дата звернення: 10.08.2019).

12. Діденко Ю.В., Радченко А.І., Коваль Н.В. Інформаційна система Web of Sciences: дзеркало чи інструмент? Наука та інноваціi. 2016. 12 (6). С. 75-84. https://doi. org/10.15407/scin 12.06 .075

13. Діденко Ю.В. Реферативна база для гуманітарних і соціальних наук ERIH PLUS. Наука України у світовому інформаційному просторі. Вип. 15. 2018. С. 66-69. URL: http://akademperiodyka.org.ua/uk/books/science_ukraine_gis/15/7 (дата звернення: 11.08.2019). 


\section{REFERENCES}

1. Kotlyarevsky, Ya.V., Radchenko, A.I., Melnikov, O.V., Semenyuk, E.P. Strategic Priorities in Measuring the Publication and Publishing Works in Scholarly Research Activity. Sci. innov. 2018, 14 (5): 5-16. https://doi.org/10.15407/scine14.05.005

2. Vakarenko, O.G. Scientometric Databases: From System of Obtaining Information to Instrument for Evaluating Scientific Research. Science of Ukraine in the Global Information Space. 2018. 15: 9-15. https://doi.org/10.15407/akademperiodyka.372.009 [in Ukrainian].

3. Tykhonkova, I.O. Strategy of Development of a Scientific Publication. Science of Ukraine in the Global Information Space. 2018. 15: 16-27. https://doi.org/10.15407/ akademperiodyka.372.016 [in Ukrainian].

4. The List of Scientific Professional Publications of Ukraine in which the results of the dissertation works for obtaining the scientific degrees of doctor and candidate of sciences can be published (as of July 11, 2019). URL: https://mon.gov.ua/en/nauka/nauka/atestaciyakadriv-vishoyi-kvalifikaciyi/naukovi-fahovi-vidannya [in Ukrainian].

5. Methodical recommendations for the introduction of digital identifiers in the publishing process for periodicals of the National Academy of Sciences of Ukraine / A.D. Danilov, A.I. Radchenko, T.M. Yatskiv; PH «Akademperiodyka» of NAS of Ukraine; SA «Ukrinformnauka». $3^{\text {rd }}$ ed., reworked and supplemented. Kyiv: Akademperiodyka, 2019. 60 p. [in Ukrainian].

6. Yatskiv, T.M., Danilova, A.D. DOI Assignment as One of Factors of Raising a Scientific Journal's Visibility. Science of Ukraine in the Global Information Space. 2018. 15: 55-65. https://doi.org/10.15407/akademperiodyka.372.055 [in Ukrainian].

7. Making full and immediate Open Access a reality. URL: https://www.coalition-s.org/

8. Directory of Open Access Journals. URL: https://doaj.org/

9. Scopus, Scimago Journal \& Country Rank. URL: https://www.scimagojr.com/

10. Web of Science Core Collection, Master Journal List. URL: http://mjl.clarivate.com/

11. ERIH PLUS. URL: https://dbh.nsd.uib.no/publiseringskanaler/erihplus/periodical/info?id=485395

12. Didenko, Y.V., Radchenko, A.I., Koval, N.V Information System Web of Sciences: Mirror or Tool? Sci. innov. 2016, 12 (6): 75-84. https://doi.org/10.15407/scin12.06.075

13. Didenko, Y.V. Reference database for the humanities and social sciences ERIH PLUS. Science of Ukraine in the Global Information Space. 2018. 15: 66-69. URL: http://akademperiodyka. org.ua/uk/books/science_ukraine_gis/15/7 [in Ukrainian].

Received 30.08.2019

\section{M.V. Yazvinska, $\mathrm{PhD}$ (Geol.)}

Scientific and Organization Department of the Presidium of the NAS of Ukraine

A.I. Radchenko, $\mathrm{PhD}$ (Geol.)

Publishing House «Akademperiodyka» of the NAS of Ukraine

\section{NAS OF UKRAINE PERIODICALS IN SOME SCIENTOMETRIC DATABASES AND THE LIST OF SCIENTIFIC PROFESSIONAL PUBLICATIONS OF UKRAINE}

The occurrence of scientific publications of the NAS of Ukraine and its institutions is analyzed in four well-known databases, among which are Scopus and Web of Science Core Collection - the two major ones for inclusion in category A of the List of Professional Publications of Ukraine. It is established that the number of academic publications open and visible to the world scientific community does not exceed $15 \%$. The extremely low activity of academic publications in entering the List of Scientific Professional Publications of Ukraine is emphasized, which will significantly complicate the procedures of protection of qualification works and certification of scientific and teaching staff in Ukraine next year.

Keywords: scientific journal, scientometric database, professional publication, NAS of Ukraine, Scopus, Web of Science Core Collection, ERICH PLUS, DOAJ, DOI. 